\title{
2
}

\section{CONNECTING THE WORLD}

\author{
Migration and globalization in \\ the second millennium ${ }^{1}$
}

\section{Leo Lucassen}

A fundamental history of globalization that puts people at the center should really start some 60,000 years ago, when homo sapiens began populating the world, starting in Africa and ending, some 45,000 years later, in the Americas. ${ }^{2}$ This chapter modestly limits itself to the most recent millennium, following the widely used approach of Held et al., who define globalization as the sustained connection between different parts of the world in terms of intensity, impact, extensity and velocity: a process that, in their eyes, did not start until the nineteenth century. I have chosen, however, to push back this time horizon so as to include earlier expressions of 'thin' globalization; in other words, the widening, deepening and accelerating of global interconnectedness between different regions of the world since the Crusades.

It is not only globalization, but also migration that is in need of a clear definition here as humans' demographic behavior is a notoriously messy and unruly phenomenon. This chapter follows the cross-cultural migration rate (CCMR) method, which was developed as a means of systematically comparing migrations over cultural boundaries in different parts of the world over longer periods. ${ }^{3}$ The method ultimately assumes that interactions between people with different sociocultural characteristics and repertoires are bound to lead to social change. ${ }^{4}$ The outcome of such interactions need not necessarily be positive, at least not for all people involved, and can result both in social development and mass killing, in genocide and in repression and subjugation. The cases of the Spaniards in Peru and Mexico, the Russians in Siberia and Europeans in Australia and North America show that such outcomes often represented two sides of the same coin. In many cases, however, the context and outcomes of cross-cultural migrations were less extreme and more balanced. ${ }^{5}$ The CCMR essentially distinguishes between four basic types of migration: 


\section{Leo Lucassen}

1 colonization (from rural to rural)

2 to cities (from rural to urban)

3 seasonal

4 temporary multi-annual (TMA).

Colonization is here defined as people who move from one rural setting to another, provided that the new destination differs in terms of ecology and culture (of the people in place). Often such migrants remain within the same political space, as in the case of the Chinese, Russian, Ottoman and Inca empires, ${ }^{6}$ or more decentralized African empires before the imposition of European rule. ${ }^{7}$ Another template involves Europeans who settled as farmers or plantation owners in overseas European colonies in Asia, Africa and the Americas. Finally, there were millions of peasants who settled in other states and continents as self-employed farmers or workers, especially in nineteenth-century America and North Asia, or as indentured wage workers in plantation economies, particularly in Southeast Asia and the Caribbean. Irrespective of whether migrants moved to different continents, in all cases they had to adjust themselves to different ecological, cultural and social circumstances and repertoires (language, religion, technology, family systems and so on), ${ }^{8}$ with the extent and direction of such adjustments depending largely on the prevailing power differentials. Migrants who were invited or who came as 'invaders' could preserve their own culture more easily than Africans taken as slaves to plantations in the Americas. In neither case, however, was the culture of the migrants entirely preserved or completely destroyed, and did processes of creolization develop. ${ }^{9}$ And in most cases these migrations contributed to the process of globalization by enhancing global interactions and the emergence of new hybrid cultures. ${ }^{10}$

The category of 'to cities' comprises migrants moving from rural to urban settings. Until the twentieth century, and in many parts of the world until this very day, such migrations had transforming influences because the institutional setting of cities differed in many ways from those in the countryside, also within the same state or polity. These migrations are of utmost importance if we want to understand social change and social development, although their impact varies and depends on the characteristics of the migrants and the opportunity structure of the specific city. ${ }^{11}$ Cities offering open access ${ }^{12}$ to a wide range of institutions and services (education, health, guilds, unions and citizenship, for example) are particularly likely to experience social change through immigration. Given the topic of this book, I have chosen to focus mainly on rural-urban migrations between world regions. This need not necessarily be limited to moves between continents, but may also include moves between culturally different regions by, for example, Chinese or Russian peasants in large cities within those territories, Mexican peasants in the United States, or Moroccan and Turkish rural workers in Europe's urbanized core.

Seasonal is defined as migrants, usually from rural areas, who spend part of the year working in a much more commercialized region, often in agriculture, but also in other sectors such as construction or brick-making. ${ }^{13}$ This type of migration, 
which is often part of the yearly work cycle of peasants who cannot live off their small plots of land alone, emerged in northwestern Europe in the sixteenth century in response to ongoing proletarianization and specialization in the countryside. It also occurred in commercialized regions in Japan, and became a widespread pattern in many parts of the world in the nineteenth and twentieth centuries. Although most migrants initially traveled only a few hundred kilometers, fast and cheap transport by boat and train meant that, from the 1860s onwards, seasonal migration also developed between continents, as the temporary migrations of Italian and Spanish golondrinas to Argentina show. ${ }^{14}$

Temporary multi-annual (TMA), finally, encapsulates all temporary migrations lasting more than a year. The best examples of this category are sailors and soldiers who leave their own cultural zone, and nomads within large empires that alternate structural mobility with settlement. ${ }^{15} \mathrm{~A}$ second example, albeit less numerous, but very important in terms of impact, is that of highly skilled 'organizational migrants', ${ }^{16}$ whose geographical mobility was determined primarily by the institutions that they joined, or were forced to serve (such as the Janissaries in the Ottoman Empire). ${ }^{17}$ The most obvious examples of this latter sub-category are missionaries, such as those who accompanied Pizarro on his trip to Peru in 1532, aid workers and skilled employees of multinational companies, starting with the early modern English and Dutch East and West India Companies. Government officials (clerks, doctors, administrators and military commanders) who migrated within colonial empires comprise a third important group, ${ }^{18}$ while the fourth and final category fitting the TMA type are pilgrims, who have played a highly interesting role in the context of globalization. Christianity and Islam, in particular, have set in motion large streams of intercontinental pilgrims since the end of the first millennium of the current era. The Hajj has drawn millions of Muslims from West Africa in the west, Siberia in the north and the Philippines in the east to Mecca since the Middle Ages. ${ }^{19}$ The same is true for the pilgrimages to the Holy Land, which were given a boost by the Crusades in the late eleventh century. ${ }^{20}$ For many pilgrims these journeys represented a transforming experience, both spiritually and culturally, while many of them stayed away for years or never came back. There are good reasons, therefore, to include these groups in our definition of cross-cultural migration. ${ }^{21}$

The importance of these four basic categories in terms of extensity, intensity, velocity and impact varies greatly from period to period. This chapter applies these analytical tools to examine three major rounds of globalization, based on the concepts of 'thin' and 'thick' globalization. I define the latter as the global convergence of prices and business cycles that started after the Napoleonic Wars, whereas the 'thin' variant pertains to the early modern period, which was characterized by global connections with low velocity and low intensity. ${ }^{22}$ I also consider partial globalization in order to examine the globalizing effects of violent and peaceful pilgrimages, warfare slave raiding and merchant activities connecting North Africa, South Asia and the Near East and Europe in the second part of the Middle Ages. 


\section{Leo Lucassen}

1 Partial globalization (c.1000-1492);

2 Thin globalization (1492-1815);

3 Thick globalization (1815 to the present).

Applying the CCMR method to these three key periods gives us a better idea of the role played by migrations in the bumpy road of globalization during the second millennium of the current era, which witnessed a myriad of interconnections between world regions through the circulation of goods, ideas and people. Rather than treating migrants simply as a given (i.e. as carriers of goods and ideas and as labor transported around the globe) I analyze them as agents (including slaves) whose cross-cultural contacts and interactions have had a transforming effect on the world they lived in, both in the past and in the present.

\section{Partial globalization: trade, war, slavery and pilgrimage (1000-1492)}

Until the end of the fifteenth century, the process of globalization was partial. The Vikings' sporadic visits to Greenland did not lead to sustained linkages, nor to permanent colonies, and the Americas therefore remained isolated. The same is true of Oceania. Other continents, however, were interlinked in many ways, albeit segmented, interrupted and rudimental. These links were created through trade, empire building, war, slavery and pilgrimage; phenomena that were often interlinked and mutually constituting. Let us look a bit more closely at the three core regions of partial globalization: the Middle East, Central Asia and the Sahara.

\section{Abbasid Caliphate}

The Abbasid Caliphate was established in the middle of the eighth century, with Baghdad as its capital, and soon covered large parts of the Middle East, Western Central Asia and the Eastern part of North Africa. Until its final demise in the sixteenth century the Caliphate played an important role in connecting Europe, North Africa and Central and South Asia. With Islam as the unifying but not exclusive religion, it stimulated the circulation of goods, people and ideas. Alongside traders, merchants and intellectuals, the state sent bureaucrats to postings throughout the empire and recruited considerable numbers of (elite) slave soldiers. These troops consisted mainly of Turkic-speaking slaves from Central Asia (Mamluk, Ghulam, Banda) who soon-despite their slave status-occupied influential positions. The Abbasid caliphs hoped to use these organizational migrants to create a trustworthy force in their vast territory. In contrast to free Turkish immigrant tribesmen, these elite slaves were detached from their family or tribes and loyal only to their masters, at least in theory. ${ }^{23}$ Although good data on their numerical strength are hard to come by, their numbers had reached approximately 10,000 by the eleventh century and, as such, they formed the nucleus of the Abbasid army. What makes these 
Turkic (Central Asian) soldiers especially interesting for the study of globalization is their involvement in the establishing of Islamic sultanates in Northern India in the early thirteenth century, and as founders of the Mamluk dynasty in Egypt in 1250, thus linking the Middle East (and Europe) more firmly to Africa and South Asia.

\section{Mongol movement}

Central Asia, especially the regions of Khorasan and Transoxania (modern-day Turkmenistan, Uzbekistan, Tajikistan, southern Kyrgyzstan and southwest Kazakhstan), was not only a well-known 'slaving zone', ${ }^{24}$ but also home to one of the most extraordinary forms of state formation in global history: the Mongol (more properly, Mongghol) Empire. Although nomadic tribes renowned as fearsome warriors had populated the large Eurasian steppe connecting China to Europe for centuries, the absence of a centralized tribal authority meant they did not pose a real threat to the empires on either side of the Eurasian landmass. ${ }^{25}$ That all changed at the start of the thirteenth century, when Remüjin unified tribes in the central Mongolian plateau (roughly equivalent to present-day Mongolia). His successor, Temüjin, who was enthroned in 1206 as Genghis Khan ('Oceanic Ruler'), became known as the founder of the Mongol Empire that occupied large tracts of China and Central Asia, including parts of Russia, with a core army of around 1 million soldiers at its peak. ${ }^{26}$ Within a few decades Mongolian forces defeated the Western Xia or Tangut Empire, and subsequently the Jin (Jurchen) dynasty, with Zhongdu (present-day Beijing) as its capital. Later, Mongolian armies conquered Korea and moved into parts of southern China as well. After Genghis Khan's death in 1227 the Mongol Empire continued to expand, including to the west, and reached its height around 1260, covering what is now China, Russia, parts of Eastern Europe, the Middle East and the Balkans.

Although the Mongols, and Genghis Khan in particular, are known for their destructive and cruel nature (similar to the dominant image of the Vikings), recent historical research stresses their role in linking East Asia to Europe, as well as the regions in between, and shows that their relationship with China was far more symbiotic than parasitic. ${ }^{27}$ Apart from the Venetian merchant Marco Polo, who traveled in the service of Kublai Kahn in the 1270s, many others moved within the largest empire the world had ever seen. First of all, soldiers and their camp followers, but then bureaucrats, merchants and settlers. And through these migrations, ideas (such as Nestorian Christianity, but also Chinese culture), state building techniques (tax collecting, monetization, military recruitment and bureaucracies), plants, animals, germs and goods were also able to circulate. They could now move in a much safer and unified 'transportation corridor' and thus extended the existing Silk Road between China and Iran. As such, the Mongol era can be regarded as a prelude to and incubator of the European seaborne empires that emerged in the fifteenth and sixteenth centuries. ${ }^{28}$ 


\section{Leo Lucassen}

\section{Crossing Africa}

Although the Eurasian highway may so far have been the focus of most historical attention when it comes to the history of globalization, Africa (at least the northern half) was also becoming increasingly integrated into the trade routes. For a long time the Sahara was the greatest obstacle. With the introduction, however, of the camel in the third century CE, North-South trade gained in importance, with the transport of slaves to the north (stretching from Morocco to Egypt) being of particular interest to us here.

As early as the mid-eleventh century onwards the Almoravids controlled an empire that linked northwestern Spain to the Ghana Empire (present-day Senegal, Mali and Southern Mauritania) in the south, thus connecting the Iberian Peninsula to Western Sudan. This resulted in large-scale, forced conversions to Islam. Meanwhile trade intensified, especially with the transition from Ghana to the Mali Empire, while Timbuktu was developing into a major trading center and its reputation was known throughout most of Europe. Salt and horses were transported south, gold from Ghana and the Upper Niger went north and was minted in North Africa (Sijilmasa, Aghmat, Marrakesh and Fez) and Spain (Seville, Cordova, Malaga and Almeria). ${ }^{29}$ Apart from gold and ivory, numerous male and female WesternSudanese slaves (some 6,000 per year between the tenth and nineteenth centuries) were raided and transported to Morocco as domestics, concubines, workers (as porters in salt and copper mines) and soldiers. ${ }^{30}$ During the reign of the Almohad caliph Muhammad an-Nasir (c.1200) the army consisted of 30,000 black soldiers, some of whom reached elite positions. On the Eastern side of North Africa, Egypt was another destination for African slaves, most of whom were employed as soldiers by subsequent regimes. As with the previously mentioned Turkic soldiers in the Abbasid Empire, these slaves were preferred because they lacked tribal affiliations and were considered to be more loyal. It is estimated that, between 650 and 1500 , over 4 million African slaves moved north, thus becoming a structural element of Mediterranean societies. ${ }^{31}$ And, as we will see later on, many more were to follow.

\section{Meanwhile in Europe: the Crusades}

Compared with the spectacular developments in Central Asia and North Africa, on the Western globalization front there was not much news. Apart from the activities of the Vikings who visited North America and linked various parts of Europe through warfare, looting, but also trade, state building and colonization, European globalizing migrations - so important at the end of the Roman Empireremained modest. ${ }^{32}$ This all changed in 1095, with the start of the First Crusade. Although small numbers of Europeans, especially German speakers, were already used to visiting Jerusalem, the call by Pope Urban II to free the holy places from the Seljuq Turks led to some 60,000 men, women and children, mainly from Germany and France, traveling to the Middle East. Interestingly, only 10 percent of them were knights. During the years of the First Crusade, some 150,000 Europeans visited Jerusalem, either as pilgrims or crusading soldiers, with some of 


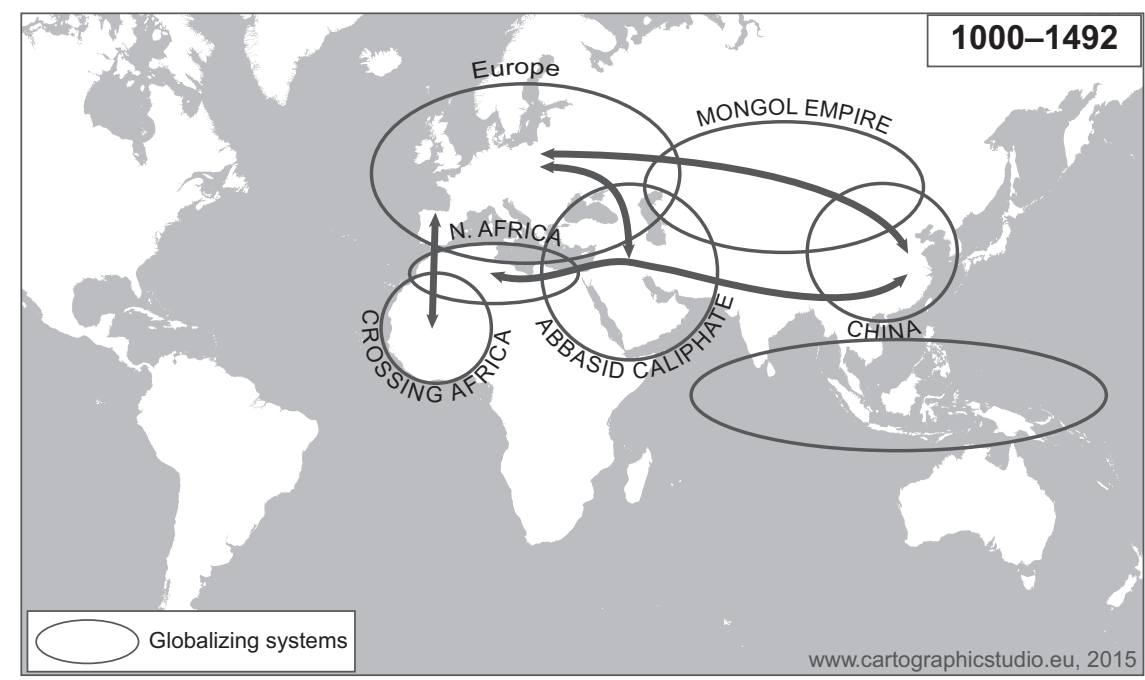

MAP 2.1 Five main globalizing systems of cross-cultural migrations (CCMs) in the age of 'partial globalization' (1000-1492)

their number staying on to settle in the Holy Land. ${ }^{33}$ Crusades continued into the twelfth century, with about half a million people moving to the Near East in the years leading up to the Last Crusade in 1216-1221, and half of these travelers (most of them French) settling for good at their destination. ${ }^{34}$

\section{Summary}

Temporary multi-annual (TMA) migrants clearly stand out when we apply our cross-cultural migration typology to the period of partial globalization.

In all the regions functioning as crossroads, soldiers, both free (Europeans and Mongols) and coerced (in the Islamic empires), formed the bulk of the migrants. A second temporary group were the pilgrims, both Christians and Muslims, who traveled great distances to Jerusalem and Mecca, which became global nodes connecting Africa, Asia and Europe. The third type of TMA migrants were merchants, who stimulated and expedited the circulation of goods, ideas and people in Eurasia, thus tying East Asia to Europe, Central Asia and Africa, both over land and over sea. Compared with the millions of TMA migrants, this period witnessed only modest numbers of interregional or intercontinental settlers (Europeans in the Holy Land, and African slaves in Moroccan mines) and migrants moving to cities.

\section{Thin globalization (1492-1815)}

\section{Migrants to the Americas}

The numbers of globalizing migrants increased from the end of the fifteenth century. However, African slaves, raided in the Horn of Africa and further south along the 


\section{Leo Lucassen}

east coast, were being transported to the Arabian Peninsula already in the eighth century and somewhat later, in smaller numbers, also to India. In total this involved about 1 million slaves prior to the early modern period and another 3 million between 1500 and the end of the nineteenth century. ${ }^{35}$ As in North Africa, many were used as soldiers, while others were domestics or worked in agriculture, infrastructure and saltpeter and salt mining. ${ }^{36}$ These considerable slave migrations from Africa to parts of Asia and Europe have always been overshadowed by the 12.5 million Africans who were transported from West Africa-and, from the 1790s onwards, also Southeast Africa ${ }^{37}$ - to the Americas (Figure 2.1). This is only partly explained by the larger numbers involved in the transatlantic slave trade. A more important explanation would seem to be the concentration of these numbers in time, as well as the active role played by Europeans, who have historically attracted much more attention from scholars.

As Figure 2.1 shows, the bulk of the slaves were forced to leave their continent of birth between the mid-eighteenth and mid-nineteenth centuries.

Europeans also settled in the Americas. Not only as slave traders, soldiers, sailors, colonists, administrators, merchants and plantation owners, but also and mainly as workers. The origins of these migrants, but also their interaction with the native population and the labor relations of newcomers in the New World, differed markedly. South America was almost exclusively populated by Spaniards and Portuguese, alongside small numbers of Dutch and French. Portuguese in particular left Europe en masse (Figure 2.2), especially given how small the population of this littoral Iberian state was. Portuguese and Spanish migrants were predominantly male and skilled, and mixed with the local indigenous population, thus producing relatively high numbers of mestizo offspring. ${ }^{38}$

In North America, migrants from the British Isles, at first predominantly English, but later on also Irish and Scottish, prevailed, while tens of thousands of German and French speakers arrived during the eighteenth century. Whereas Iberian

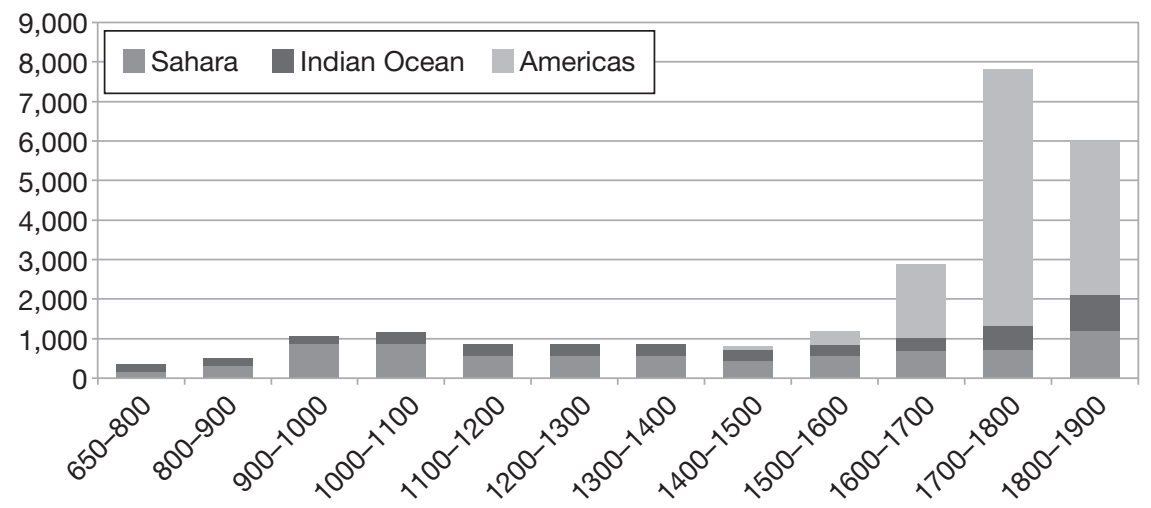

FIGURE 2.1 External destinations of slaves transported from sub-Saharan Africa, 650-1900 (x 000) 
migrants in the South overwhelmingly settled in cities and were mainly found in middle-class occupations, northwestern Europeans in North America were mainly indentured servants (more than 50 percent in the period 1600-1800), working and living on farms. ${ }^{39}$ These colonists occupied land that was sometimes bought, but mostly simply violently appropriated from native Americans, while a minority established itself in small, but growing cities such as Boston, New York, Philadelphia, Newport, Albany, Jersey City, Charleston and Baltimore. The low urbanization rate in North America at that time (3-6 percent in 1800) contrasts sharply with Europe (12 percent for Europe as a whole and 21 percent for Western Europe) and somewhat less with Latin America (7 percent). ${ }^{40}$

As Figure 2.2 shows, migrants from northwest Europe were much less numerous in the Americas than those from Spain and Portugal until the mid-eighteenth century. In 1775, the thirteen colonies consisted of only 2.5 million settlers, but from then on grew rapidly and surpassed the population of the United Kingdom in 1820, when the US census counted 9.6 million inhabitants, 1.5 million of whom were slaves. In contrast to the Iberian invaders of Latin America, northern

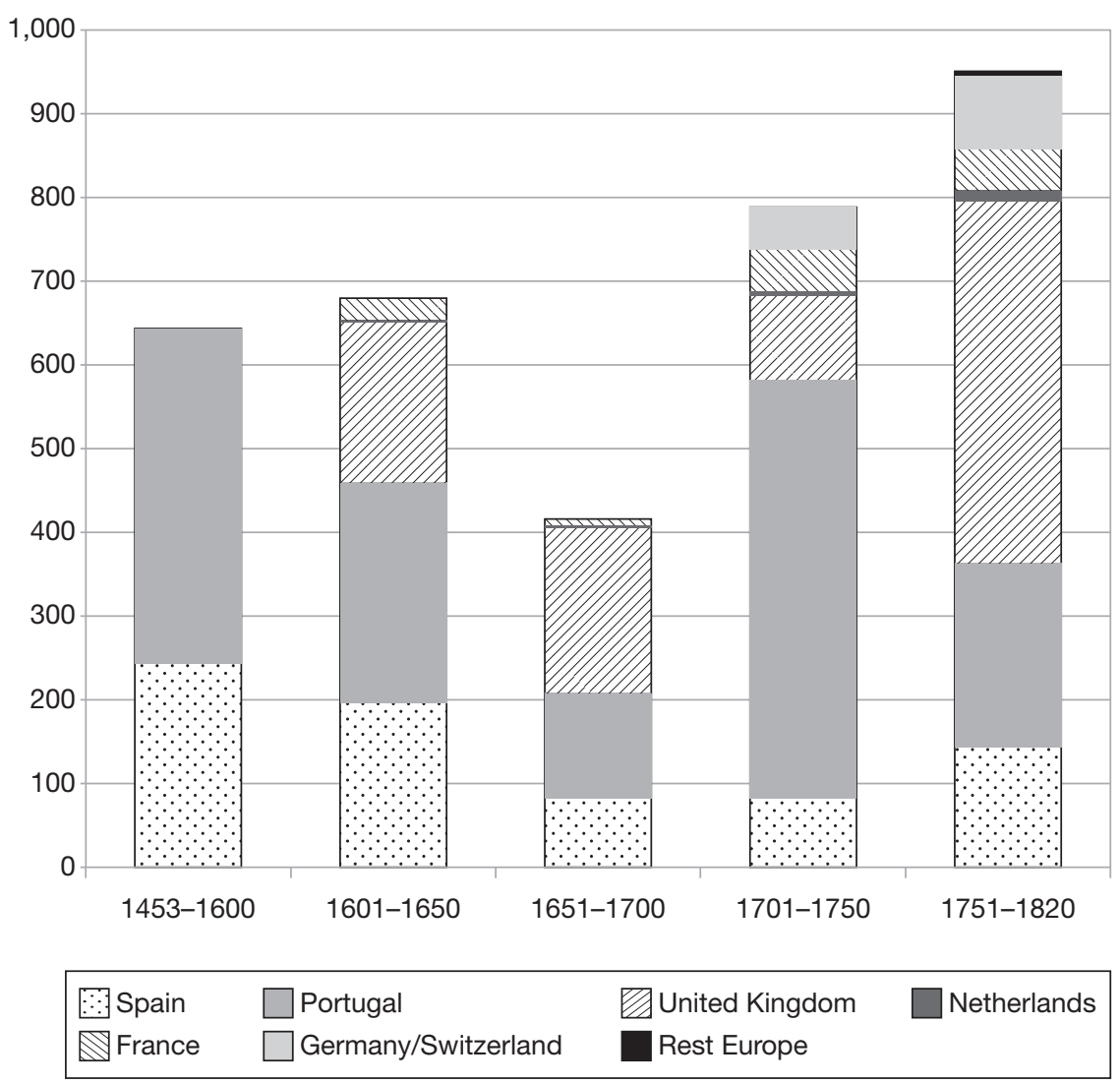

FIGURE 2.2 Emigration from Europe to the Americas, 1493-1820 (x 000) 


\section{Leo Lucassen}

Europeans more or less transplanted their old-country communities to the New World and, as far as they mixed, preferred other Europeans. Compared with the forced immigrants from Africa, however, Europeans in the Americas dwindled almost into insignificance, at least between the mid-seventeenth and early nineteenth centuries (Figure 2.3).

The demographic impact of globalization on the regions of departure and arrival in this period differed widely. The consequences for sub-Saharan Africa, especially West Africa, Angola, Mozambique, the Horn of Africa and the Swahili Coast (see Map 2.2), were dramatic, given that, during the course of a millennium, between 3,000 and 75,000 individuals each year were forcibly moved over long distances, with most of them leaving Africa for good. This organized long-distance and intercontinental slave trade was much more significant than slave systems within Africa as, with the exception of the Songhai Empire in West Africa between the fourteenth and sixteenth centuries, the number of people with slave status in Africa was relatively low. ${ }^{41}$ Europe's share of emigrants was much lower, and the disruptive effects of out-migration paled into insignificance in comparison with

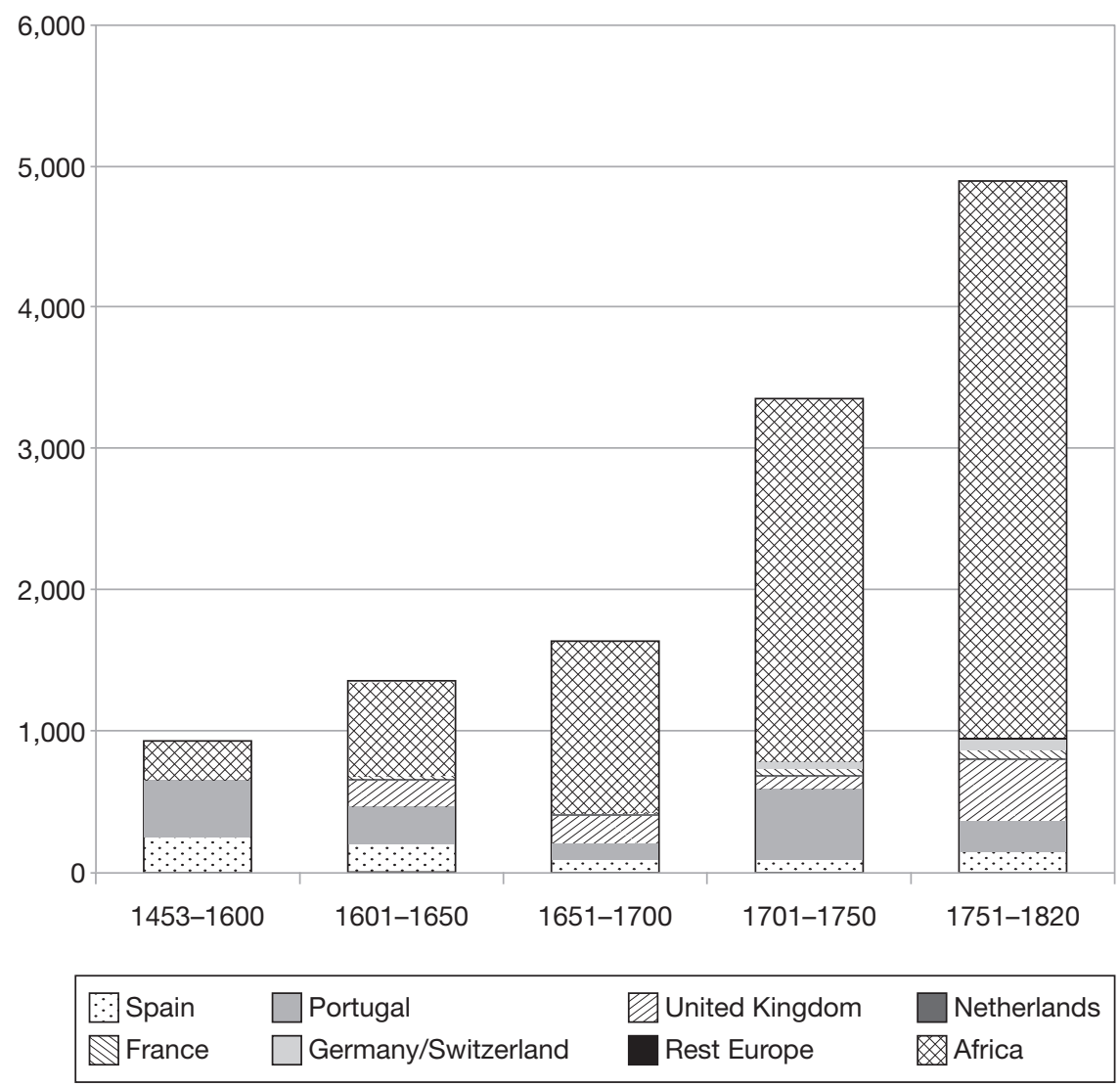

FIGURE 2.3 Emigration from Europe and Africa to the Americas, 1493-1820 (x 000) 


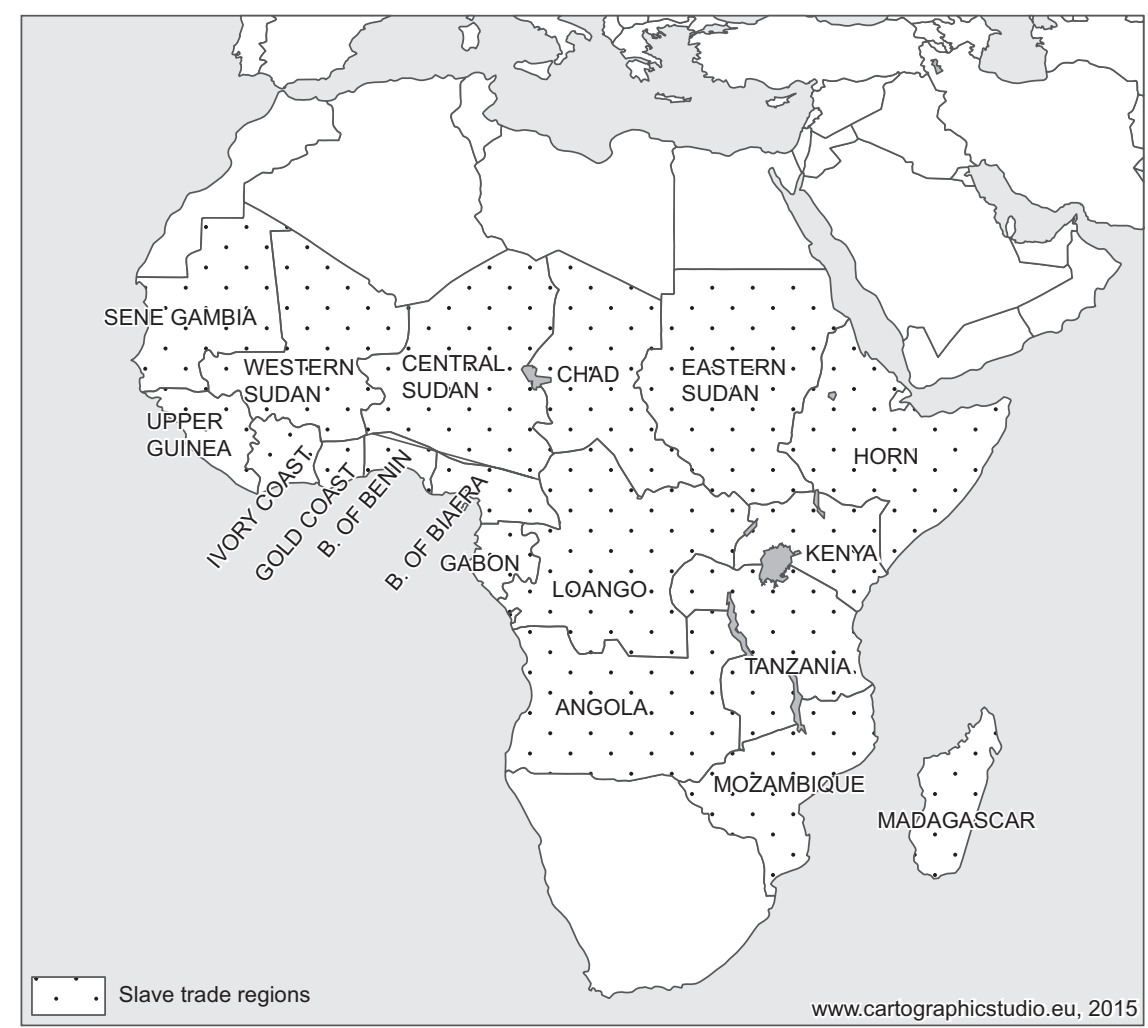

MAP 2.2 Slave trade regions in Africa

large parts of Africa, which were ravaged by slave raiders. So whereas the major European sending regions saw their populations increase by around 150 percent between 1600 and 1820 (and, in the case of the British Isles and Portugal, even by 300 percent and more), the size of Africa's population, which had been around 140 million in 1600 , stagnated until the early twentieth century. ${ }^{42}$ Finally, the demographic impact that migrations from Africa and Europe had on the Americas was catastrophic as the native Indians were ravaged by the spread of contagious diseases such as smallpox, measles and influenza, from which the population took up to one to two centuries to recover. ${ }^{43}$

\section{Mediterranean exchange}

In the period of partial globalization we encountered Muslim merchants and slave raiders from the Middle East who were very active along the East African coast. From the end of the fifteenth century they were joined by Europeans, however not only as slave traders, but also as captives of pirates from North African states who boarded European ships and systematically raided areas along the northern 


\section{Leo Lucassen}

Mediterranean coast. By 1800, some 600,000 European sailors, soldiers and merchants had been enslaved and sold at markets in places such as Algiers. After a while, some of these captives were released in return for payment of ransom money. The often dramatic histories of the savage and cruel North African 'Barbary coast' are, however, rather one-sided. The full story is that, during the early modern period, the entire Mediterranean was a slave-hunting ground for Christian and Muslim states alike. Demand was especially high for galley slaves, as well as for plantation workers (particularly in the south of Portugal) and domestics. European states were more succesful in this competition as they were able to bring almost 600,000 Muslim capitives to Italy and 375,000 African slaves to the Iberian Peninsula. In 1616, for example, there were some 3,000 Muslim slaves living in Livorno, who were allowed their own mosque and cemetery so as to enforce equal rights for Christian slaves in North Africa. ${ }^{44}$ If we extend the space somewhat to the east and include the Ottoman Empire, we see yet another slavery circuit emerging. This circuit comprised the 3 million Eastern Europeans who were systematically raided by Caucasian Tatars as far north as the Baltic states and then sold at slave markets in the Middle East, some of whom eventually ended up as domestic slaves in Italian cities. ${ }^{45}$ Finally, there were tens of thousands of Christian boys from the Balkans, the Janissaries, who had been raised and trained since the fifteenth century to become elite Ottoman troops. ${ }^{46}$

Although slave raiding dominated the Mediterranean exchange, other movements also took place, with the best examples of these being the 270,000 Spanish Muslims and 75,000 Iberian Jews who were expelled by the Catholic rulers in the sixteenth and seventeenth centuries and who found refuge in North Africa and the Ottoman Empire. But also within empires, mobility was more rule than exception, as the permanent migrations of tribal nomads and soldiers within the Ottoman Empire, linking Asia to Europe and North Africa, illustrates. ${ }^{47}$ These temporary and permanent intercontinental population exchanges in an albeit segmented Mediterranean space added to the globalization process through different religious, cultural and technological values and expertise being mixed and adapted at these crossroads between Europe, Africa and Asia.

\section{Indian Ocean}

As we saw in the period of partial globalization, the Indian Ocean is at least as important when it comes to migrations between continents and between different regions of Asia. Until recently, the conventional story started with Bartolomeu Dias who rounded the Cabo das Tormentas (later Cabo da Bõa Esperança) in 1488, soon followed by the Portuguese, Dutch, English and French, who established trading networks and outposts and eventually colonized large parts of Asia. However, the Indian Ocean had been connected from east to west long before Europeans tapped into the existing Indian Ocean trade and religious networks that linked Japan and China in the Far East through Southeast Asia to India, the Near East and the East Coast of Africa. ${ }^{48}$ 
Millions of Europeans sailed to Asia during the period of thin globalization, most of them as soldiers and sailors. The Dutch Republic alone saw 1 million men (and very few women) leave its ports, almost half of whom were foreigners from Scandinavia or German-speaking countries. ${ }^{49}$ Similar numbers traveled on Asiabound ships from Great Britain, Spain, Portugal and, to a lesser extent, France. In total, therefore, a rough estimate for the period 1500-1800 shows that some 2 million Europeans went to Asia. ${ }^{50}$ Of these, around a quarter to a third succumbed to tropical diseases, while others settled for good (and mixed with the native population) and large numbers returned and shared their experiences (and exotic goods) with their home communities. Until the nineteenth century, the various East India Companies who took the lead in crossing to Asia touched only the littoral fringes of Asian societies, most of them in the south and south-east. China and Japan were largely left untouched, with trade contacts being particularly restricted in the case of Japan. Only the Dutch were allowed to maintain links, albeit limited to the artificial island of Dejima in Nagasaki Bay. As in China, Japan's imperial rulers wanted to minimize cultural and, particularly, Christian religious influences. Missionaries such as the Jesuits were completely banned from Japan in 1614 and converts were executed. In China on the other hand, where Italian and Portuguese Jesuits had played an important role as mediators transmitting European science from 1583 onwards, Catholics were permitted, while a small native Christian community in Beijing was also tolerated. ${ }^{51}$ Most of these 'migrants', however, were banned from the provinces and limited to the imperial court, where their scientific and technical knowledge was highly valued and where Jesuits became the official court astronomers. A number of Chinese neo-Confucian intellectuals converted to Christianity and played an important role in translating Western studies into Mandarin. ${ }^{52}$ This changed with the transition to the Qing dynasty in 1644; the position of the Jesuits then gradually deteriorated until, in 1746, anti-Christian laws were promulgated and numerous missionaries were executed. Knowledge did not only travel eastwards, however, as trade contacts resulted in Chinese inventions such as gunpowder, inoculation against smallpox, block printing and porcelain being adopted in Europe and other parts of the world.

Globalizing influences were not transmitted only through European trade and missionary networks. Chinese merchants and peddlers also ventured out, especially to southeastern China, while Central Asians (Mongols), Russians and Tibetans were in constant contact with Han Chinese on China's western border. People not only crossed borders, but borders also crossed people, as in the case of the Qing conquest of the Xinjiang region in Central Asia. China's only serious competitor in the region was Russia, which built up geopolitical pressure in the area by expanding into Siberia in the seventeenth century and, by 1643, reaching the river Amur, close to the Manchu heartland. China and Russia ultimately signed various treaties designed to avoid armed conflict and, other than trade, Russian influence on China is visible in the calibration of the borders, which was done with the help of land measurement techniques introduced by the Jesuits. 


\section{Leo Lucassen}

\section{Summary}

The most spectacular change in the period of thin globalization was the 'discovery' of the Americas. The human web started unfolding dramatically as soon as Columbus reached Guanahani (now one of the Bahamas Islands). The Atlantic, far more so than the Pacific, then became the core space of globalization. The migrations that accompanied this were highly asymmetrical. Whereas animals and plants moved in both directions, the circulation of people was rather one-sided, with Africans and Europeans going west and (apart from return migrants) almost no-one moving east. This is also reflected in the cultural impact that the coerced and free colonists had on the New World, where European institutions, languages and religions were imported, as well as European and African genes, family systems and a wide range of cultural practices, including material (such as clothing styles and food habits) and popular cultures (music, literature). These imports were then modified, appropriated and changed, depending on the specific human and ecological interactions, to produce new American syncretizations.

If we now apply our cross-cultural migration typology we can conclude that the world regions distinguished above and summarized in Map 2.3 can be subdivided into two main categories: immigration and emigration.

\section{A: Immigration}

1) The Americas: here, the bulk of the migrants fit into the colonization type, moving from 'rural to rural' and settling as farmers, plantation owners and workers (predominantly coerced). In Brazil and the Caribbean, Africans were brought in as chattel slaves after failed experiments with European workers, whereas much smaller numbers of indentured European servants ended up in North America, where they were soon outnumbered by slaves. Latin America diverges from this pattern as most Spaniards and Portuguese settled in cities and fit the to cities type.

2) The Mediterranean and the Middle East: here, colonization also dominated, although most of the migrants were forcibly brought to these regions as slaves, either from the South (Africa) or the North (Eastern Europe).

3) South, Southeast and East Asia: these regions received predominantly soldiers and sailors, and small numbers of merchants and missionaries, all of them to be subsumed under the temporary multi-annual (TMA) heading.

4) East Asia: China, Korea and Japan remained in contact with the same world regions as in the previous period of partial globalization, but these contacts were limited to certain cities and under strict state surveillance. Furthermore, this region did not establish demographic links with the Americas by sending or receiving populations. Although the small numbers of TMA merchants, scholars and missionaries who visited East Asia stimulated cross-cultural interactions, they left these societies largely untouched, apart from certain scientific and religious ideas, goods and silver bullion. 


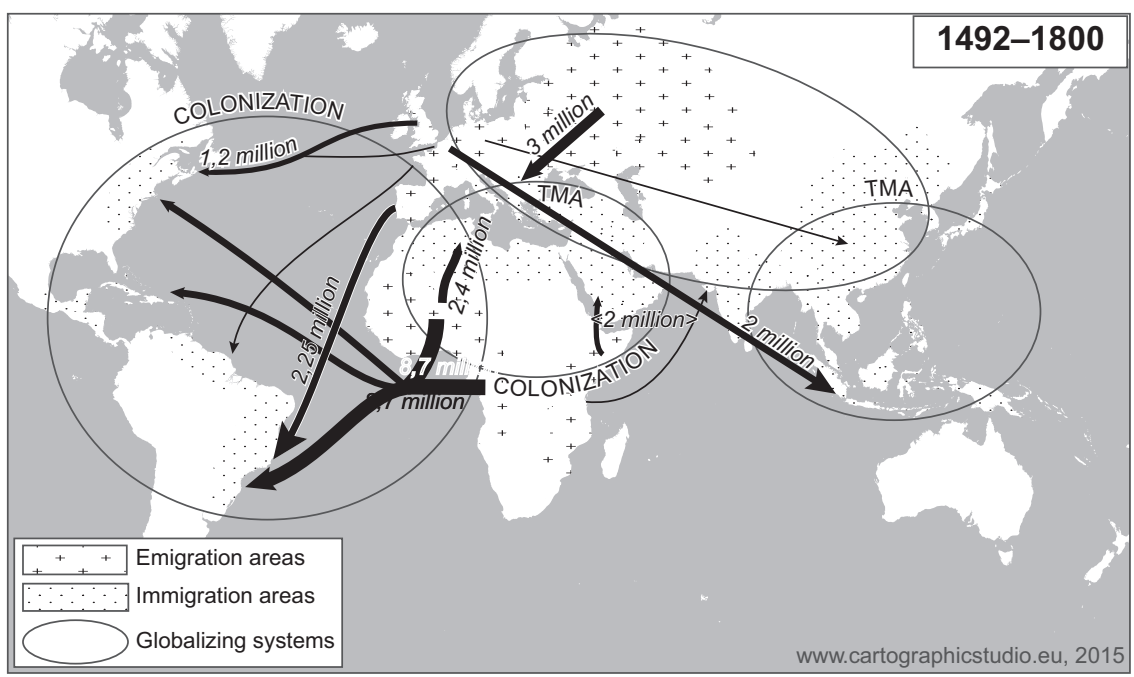

MAP 2.3 Four major globalizing systems of cross-cultural migrations (CCMs) in the age of 'thin globalization' (1492-1800).

\section{B: Emigration}

This leaves us with two world regions, Western Europe and Africa, which were also deeply influenced by globalization, but mainly through out-migration. The big difference between the two was that Africans were forced into migration, while Europeans were more or less free (notwithstanding all kinds of indentured forms of labor migration) and return migrants brought back all kinds of mental and material influences to those who had stayed behind. As a result out-migration from Africa resulted in demographic and economic stagnation, whereas Western Europe profited from the infusion of new ideas and widening mental horizons of returnees, as well as from obtaining access to cheap raw materials and large quantities of silver.

\section{Thick globalization (1815 to the present)}

\section{A) Phase 1: segmented systems}

The long nineteenth century (1815-1914) is known as the era of mass migration. For a long time, historians' gaze was fixed on the Atlantic, which some 50 to 60 million Europeans crossed to settle in North and South America. During this period another 4 million forced migrants from Africa arrived after 1815. Recently, scholars specializing in Asia have fundamentally questioned this 'Atlanto-centrism' by pointing to the similar numbers of long-distance migrants in North and Southeast Asia (Table 2.1). The rhythms and business cycles of the three systems were also clearly very similar since they were all reacting to the globalized world economy. 


\section{Leo Lucassen}

Before looking at the separate migration systems in more detail, we should realize that the nature of these mass migrations differed considerably. Whereas, in contrast to the previous period, the bulk of the (mainly European) transatlantic migrants ended up in cities, labor migrants from India and China who moved to plantation economies in Indonesia, Malaya and Burma (and, by comparison, the trickle that moved to the Caribbean, Fiji and Mauritius) were much more circular and, as such, fit into the seasonal and TMA categories. Finally, North Asia (including Japan, Manchuria and southeast Siberia) is a mix of colonization, TMA and, to a lesser extent, migrations to cities, with newcomers originating mainly from and within China and Russia.

As Adam McKeown has forcibly argued, the division into three major and interlinked world systems is not explained only by economic factors. After the initial recruitment of Chinese workers needed to meet the sudden demand for miners during the Californian and Australian Gold Rush, the Atlantic was largely closed to Asian migrants from the late nineteenth century, starting with the Chinese Exclusion Act of 1882 in the United States. American and Canadian employers soon turned to Japanese migrants, who were subsequently banned in 1907 under the 'gentlemen's agreement' between the United States and Japan. Asian-Pacific migration then shifted to Latin America, with Brazil welcoming almost 200,000 Japanese Dekasegi, mostly as small landowners, between 1908 and 1940 (and another 50,000 in the 1950s). ${ }^{53}$ Although Chinese and Japanese merchants and students were still allowed into North America, the chance to migrate beyond Asia decreased significantly for most Asians during this period, despite the existence of various loopholes.

TABLE 2.1 Major long-distance flows (1846-1940)

\begin{tabular}{|c|c|c|c|c|}
\hline Destinations & Origins & $\begin{array}{l}\text { Numbers } \\
\text { (millions) }\end{array}$ & $\begin{array}{l}\text { Auxiliary } \\
\text { origins }\end{array}$ & $\begin{array}{l}\text { Dominant } \\
\text { CCM type }\end{array}$ \\
\hline Americas & Europe & $55-58$ & $\begin{array}{l}2.5 \text { (from India, } \\
\text { China, Japan } \\
\text { and Africa) }\end{array}$ & To cities \\
\hline $\begin{array}{l}\text { Southeast Asia } \\
\text { (incl. Assam, } \\
\text { Indian Ocean } \\
\text { Rim, South } \\
\text { Pacific) }\end{array}$ & $\begin{array}{l}\text { India and } \\
\text { Southern } \\
\text { China }\end{array}$ & $51-55$ & $\begin{array}{l}4 \text { (from Africa, } \\
\text { Europe, } \\
\text { Northeast Asia, } \\
\text { Middle East) }\end{array}$ & TMA/Seasonal \\
\hline $\begin{array}{l}\text { North Asia } \\
\text { (incl. Manchuria, } \\
\text { Siberia, Central } \\
\text { Asia, Japan) }\end{array}$ & $\begin{array}{l}\text { Northeast } \\
\text { Asia, Russia }\end{array}$ & $46-51$ & & $\begin{array}{l}\text { Colonization/ } \\
\text { TMA }\end{array}$ \\
\hline
\end{tabular}

Source: A. McKeown, Global migration 1846-1940, Journal of World History, 15(2), 2014, p. 156. For Assam see: R. Behal, One hundred years of servitude: political economy of tea plantations in Colonial Assam, New Delhi: Tulika, 2014. 


\section{Colonial plantations, colonial circuits and global warfare}

The Atlantic and Asian mass migrations mobilized much larger shares of the population, with these 150-200 million migrants linking the world as a whole much more intensively than ever before. This is especially true for the imperial and colonial circuits, which partly developed independently of the three major long-distance flows mentioned above. If we define 'colonial' broadly, this will include not only the 'usual suspects' of Great Britain, France, the Netherlands, Italy, Portugal and Japan, but also the United States, Russia, Turkey and Germany. In the period of nation-state formation, all these states developed circuits that linked the metropole with formal colonies, or the frontiers of formal and informal empires. The migrations generated by such circuits had some overlap with the three major systems in Table 2.1, but only very partially. We can roughly distinguish two broad categories. First of all, people who were sent by imperial states, or who left on

TABLE 2.2 Major (people) plantations by imperial states (1851-1950)

\begin{tabular}{llll}
\hline Origins & Destinations & $\begin{array}{l}\text { Numbers } \\
\text { (millions) }\end{array}$ & $\begin{array}{l}\text { Dominant } \\
\text { CCM type }\end{array}$ \\
\hline $\begin{array}{l}\text { Russia } \\
\text { Great Britain }\end{array}$ & $\begin{array}{l}\text { Siberia, Central Asia } \\
\text { Dominions (Canada, } \\
\text { Australia, New Zealand } \\
\text { and South Africa) }\end{array}$ & 17 & $\begin{array}{l}\text { To cities } \\
\text { To cities and a minority } \\
\text { to rural areas (colonization) }\end{array}$ \\
France & Algeria & 5 & $\begin{array}{l}\text { To cities and to rural areas } \\
\text { (colonization) }\end{array}$ \\
Japan & Manchuria, Taiwan, & 2.5 & $\begin{array}{l}\text { To cities and a minority to } \\
\text { rural areas (colonization) } \\
\text { Germany }\end{array}$ \\
Korea, South Sakhalin & Poland (1939-1945) & 1 & $\begin{array}{l}\text { To rural areas (colonization) } \\
\text { and a minority to cities } \\
\text { Portugal }\end{array}$ \\
Spain & Angola, Mozambique & 0.5 & $\begin{array}{l}\text { Colonization } \\
\text { Algeria, other African } \\
\text { Total }\end{array}$ \\
\hline
\end{tabular}

Sources: J. Lucassen and L. Lucassen, The mobility transition in Europe revisited, 1500-1900: sources and methods, IISH Research Papers, Amsterdam: International Institute of Social History, 2010; J. Lucassen and L. Lucassen (eds), Globalising migration history. The Eurasian experience (16th-21st centuries), Leiden and Boston, MA: Brill, 2014; L. Lucassen, J. Lucassen, R. de Jong and M. van de Water, 'Cross-cultural migration in Europe 1901-2000: a preliminary estimate', IISH Research Papers, Amsterdam: International Institute of Social History, 2014; P. Polian, Against their will: the history and geography of forced migrations in the USSR, Budapest: CEU Press, 2004. I. Heinemann, “Volksdeutsche”Umsiedler in Deutschland und in von Deutschland besetzten Gebieten im Zweiten Weltkrieg, in K. J. Bade, P. C. Emmer, L. Lucassen and J. Oltmer (eds), Enzyklopädie Migration in Europa vom 17. Jahrhundert bis zur Gegenwart, Paderborn and Munich: Wilhelm Fink Verlag/Ferdinand-Schöningh-Verlag, 2007, p. 1081; L. H. Siegelbaum and L. P. Moch, Broad is my native land: repertoires and regimes of migration in Russia's twentieth century, Ithaca, NY and London: Cornell University Press, 2014. 


\section{Leo Lucassen}

their own initiative, to settle at the periphery of the empire or in other, conquered, territories (colonies). As Table 2.2 shows, this involved over 30 million people, concentrated in the first half of the twentieth century.

The influence of these colonizing migrants on the receiving societies differed greatly. Whereas British (and other European) migrants marginalized the indigenous populations of New Zealand, Australia and Canada and installed a rigid apartheid system in South Africa, the French (joined by Spanish and Italian settlers) in Algeria had a less devastatingly pervasive influence, with North African languages, religions and institutions remaining largely intact. Russian and Japanese settlers could be placed somewhere in between, being more successful in promoting the culture (broadly defined) of the core.

When we combine the three systems identified by McKeown with the considerable numbers of forced settlers and organized migrants within Russia and the organizational (TMA) migrants in the various colonial circuits, we arrive at the following map:

A second category of migrants that navigated the colonial circuit were the soldiers (and sailors) who were used to conquer or control the colonial state. Many of them were recruited locally, such as the Zouaouas soldiers (Igawawen in the local Berber language) from the tribal confederation of Kabylia, who had previously been fighting for the Ottoman Empire. The French called them Zouaves, but soon afterwards created the Turcos (tirailleurs), thus changing the origins of the Zouave corps, which from then onwards was predominantly of European origin. ${ }^{54}$ Apart from these indigenous troops, nineteenth-century European colonial powers engaged some 6 million European soldiers overseas. The French alone stationed 1.6 million French

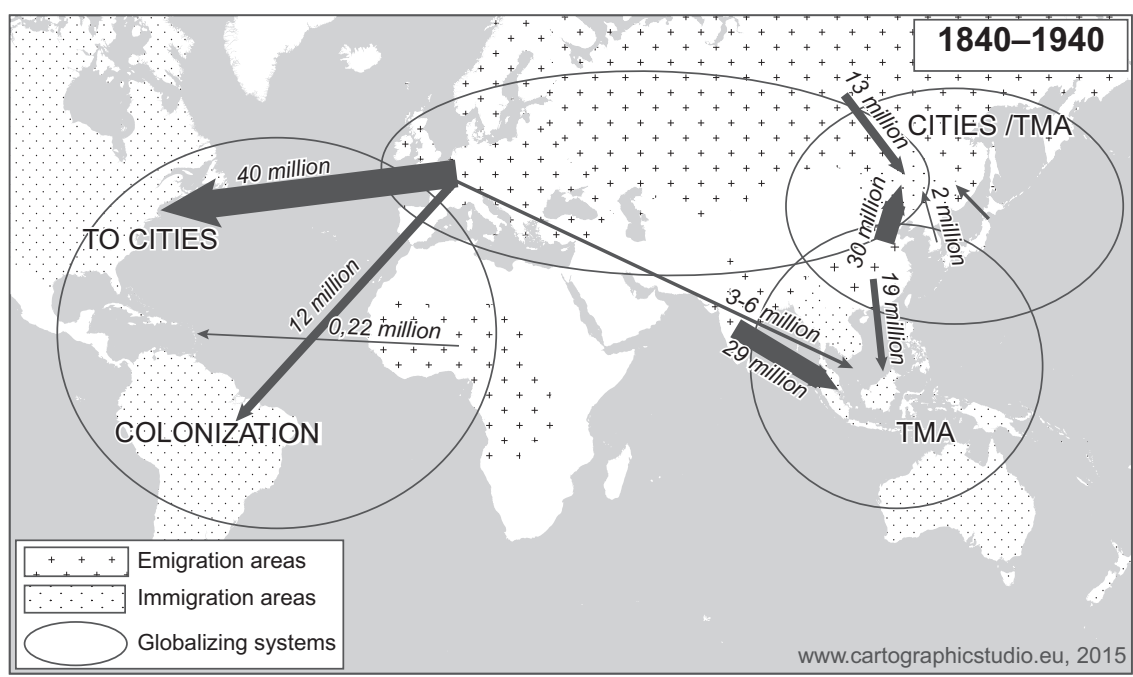

MAP 2.4 Five major globalizing systems of cross-cultural migrations (CCMs) in the age of 'thick globalization' (1840-1940) 
soldiers in Algeria. ${ }^{55}$ In the twentieth century, the number of soldiers who were sent to other continents or who moved within transcontinental empires, such as Russia, increased dramatically, with up to 60 million people involved in these migrations. We can roughly distinguish seven major 'sending sources':

Not surprisingly, the United States sent out by far the largest number of soldiers, not only during the two World Wars, but also, from 1945 onwards, to bases around the world (especially in Japan and what was then West Germany) during the Cold War, and also to fight in Korea, Vietnam, Afghanistan and Iraq. Russia (or the Soviet Union) follows at some distance, with most of its soldiers abroad stationed in East Germany and, in the 1980s, Afghanistan. Japan started its imperial expansion in 1895 by occupying Taiwan and continued to broaden its sphere of influence until the armistice in 1945. During the twentieth century, as in the nineteenth century, millions of European soldiers also traveled to overseas colonies to try to keep order and repress rebellions. China's troops, by contrast, were overwhelmingly active inside China and, with the exception of the 3 million soldiers deployed in the Korean War (the same number mobilized by the British Dominions during the two World Wars), do not count as global cross-cultural migrants. Finally, at least 2 million Asians, Africans and West Indians were recruited

TABLE 2.3 Soldiers as global cross-cultural migrants worldwide in the twentieth century (millions)

\begin{tabular}{|c|c|c|c|c|c|}
\hline & $\begin{array}{l}\text { Imperial } \\
\text { expansion } \\
1900-45\end{array}$ & $W W I$ & $W W I I$ & $\begin{array}{l}\text { Post- } \\
W W I I\end{array}$ & Total \\
\hline United States & & 2 & 12 & 20 & 34 \\
\hline Russia & & & & 8 & 8 \\
\hline Japan & 6 & & 6 & & \\
\hline Europeans to the colonies & 2.5 & & & 2.5 & 5 \\
\hline China & & & & 3 & 3 \\
\hline British dominions & & 1 & 2 & & 3 \\
\hline $\begin{array}{l}\text { Asian, African and West } \\
\text { Indian colonial troops } \\
\text { outside their country of } \\
\text { origin }\end{array}$ & & 1 & 1 & & 2 \\
\hline Total & & & & & 61 \\
\hline
\end{tabular}

Sources: Lucassen and Lucassen, The mobility transition in Europe revisited', 2010; Lucassen, Lucassen, de Jong and van de Water, 'Cross-cultural migration in Europe 1901-2000', 2014; M. Höhn and S. Moon (eds), Over there: living with the US military empire from World War Two to the present, Durham, NC: Duke University Press, 2010; D. Horner, World War II, the Pacific, New York: The Rosen Publishing Group, 2010, pp. 21-2; X. Li (ed.), China at war: an encyclopedia, Santa Barbara, CA: ABC-Clio, 2012, p. 65; A. Solimano, Globalization, history and international migration: a view from Latin America, Geneva, ILO, 2004, p. 19. 


\section{Leo Lucassen}

during this period by the British and the French to serve as soldiers, both in Europe and Southeast Asia.

These impressive numbers of soldiers were important agents of globalization. They not only killed, raped and looted, but, due to their power and status, also introduced the culture of their home countries in the form of languages, consumption patterns, world views, music and movies, as well as various institutions. In this way, they deeply influenced the regions where they were active. At the same time, soldiers themselves changed, too, as did the societies they returned to after their tours of duty. A telling example is that of the hundreds of thousands of black American GIs during and after World War II, for many of whom their time abroad was the first time they had experienced societies that were not racially segregated. This made them realize that the widespread, institutionalized racial discrimination of the United States was not normal, and many of them, upon their return, became active in the civil rights movement. ${ }^{56}$

One of the additional effects that wars and military interventions have is considerable levels of migration from the targeted regions. This explains the present-day communities of Vietnamese in France and the United States, the Eurasians in the Netherlands and Koreans in Japan. The size of these counter-flows caused by 'backward linkages' does not necessarily reflect the number of metropole soldiers received by these regions. Small numbers of soldiers (or 'military advisors') can destabilize societies to such an extent that they result in large-scale emigrations, as clearly demonstrated by the US interventions in Central America and Cuba from the 1960 s onwards. ${ }^{57}$

The fact that temporary multi-annual migrants need not be large in number to have a profound cross-cultural impact also becomes clear when we take a closer look at the highly skilled organizational migrants who were invested with power and status both within and outside colonial circuits and thus spread new ideas, religions, languages, techniques and consumption patterns. Missionaries, aid workers, engineers, diplomats, expats working for multinational corporations and foreign students all belong to this category. ${ }^{58}$ The assessment of their impact may differ radically depending on one's interests and political position. There are ample examples of ecological and cultural damage and destruction wrought by such organizational migrants, while such asymmetrical cross-cultural influences were often adapted and appropriated in unexpected ways, or simply rejected. Others, however, profited from the temporary presence of these organizational migrants or welcomed what they had to offer.

Lastly, we should not see this process as purely a process of Western imperialism. First of all, non-Western states and regions were also involved in such migrations. Just think of the thousands of Cuban doctors sent to Latin America countries and Africa in the years following the Cuban Revolution in 1959, or the 200,000 Soviet 'twenty-five-thousanders', representing the vanguard of the revolution in the countryside, who were sent to faraway Siberia or Central Asia in the 1930s. ${ }^{59}$ Or the Chinese specialists in Tibet and, nowadays, in Africa, or Japanese bureaucrats, scholars and other professionals in Taiwan and the Dutch East Indies before and 
during World War II. And, last but not least, we should not forget the students who bring home new technological and ideological ideas from their time at foreign universities. Again, the implementation could be disastrous or benign, depending on the situation and on one's perspective. Few, however, would applaud the effects that cross-cultural migration had in the case of Saloth Sar (better known as Pol Pot), who was influenced by revolutionary ideas as a student in Paris in the late 1940s and who developed a genocidal form of communism that cost the lives of 2.4 million Cambodians between 1975 and 1979.

\section{B) Phase 2: opening up the Americas}

Global migration systems changed significantly in the second half of the twentieth century, and the changes are explained by the following five factors:

1) Taboo on racism. The traditional immigration countries in North America and the Western offshoots in Oceania (Australia and New Zealand) continued to pursue racially based immigration policies until the 1960s. The American Quota Acts from the 1920s and the 'White Australia' policies made it very difficult for Asians, Africans and migrants from Latin America to migrate and settle there. Immigration policies in those countries changed, however, in response to the new, post-war humanitarian regime and fundamental international (UNESCO, UNHCR, UN) criticism of racism. The best example is the United States' 1965 Immigration and Nationality Act, which abolished the 'national origins formula' that was heavily biased towards European immigrants and switched instead to focusing much more on new immigrants' skills and family relationships. This shift from race to human capital was an important factor in changing the global cross-cultural migration systems from the 1960s onwards and opened the North Atlantic system to skilled newcomers from all over the world, especially Asia and, to a lesser extent, Africa. Their numbers have consequently swelled, especially since the 1980s, with cheaper air fares, rising educational standards and economic growth in Asia and some parts of Africa widening the pool of eligible migrants. The demise of racial criteria was not, however, the only factor that led to truly globalized migration systems.

2) Welfare state. A second shift in migration dynamics was the largely unintended effect of temporary labor migration systems operating in liberal democracies in Western Europe ('guest workers') and the United States (Bracero program). In both cases, the intended temporary stays of these migrants soon became permanent, largely because few had foreseen that, by legally entering the territory, these individuals also built up legal and social rights that made it very difficult, and often impossible, to refuse them permanent settlement. ${ }^{60}$ This 'liberal paradox' was absent in the Middle East, where oil states also attracted large numbers of guest workers, mainly from South and Southeast Asia, but without granting them any legal or social rights.

3) Decolonization. A third important factor in globalizing migration systems was the demise of the colonial empires that triggered a number of postcolonial migration streams to 'mother countries' such as Great Britain (from the West Indies and South 


\section{Leo Lucassen}

Asia from the late 1940s onwards), France (from Algeria and other African countries and Indochina), Portugal (Angola and Mozambique), and the Netherlands (Indonesia and Suriname). Although most of these metropoles were not keen to receive these (former) subjects, they were unable-for legal and ideological reasons - to prevent them from settling and only gradually tightened their immigration legislation. Some former colonial powers or countries that felt special ties to what-for ethnic or political reasons-they regarded as 'their people' even actively encouraged immigration from afar. ${ }^{61}$ Well-known examples of such countries include Israel (Jews from all over the globe), Germany (Eastern European Volksdeutschen, and Aussiedler from the former Soviet Union), but also Spain, Portugal, Italy, Turkey and Japan (returnees from the former empire in Asia), with all of these countries making it easy for descendants of erstwhile emigrants to become citizens. And, in the case of Spain and Japan, hundreds of thousands of these 'ethnic immigrants' took the opportunity during the Latin American debt crisis in the 1980s and 1990s to return to the country of their forefathers. Summarized, the picture is as follows:

Recently this ethno-national stance has also been activated by China, aiming to lure back 'overseas Chinese' in the hope that their economic and human capital will further boost China's economic and political position. ${ }^{62} \mathrm{We}$ can also see a similar trend in India.

4) Cold War and other 'backward linkages'. As we discussed earlier, soldiers became important agents of globalization in the short twentieth century, not only through their own migrations and return migrations, but also because they forged new links between their home country and the regions they occupied or in which they were

TABLE 2.4 Postcolonial immigrants and their proportion of the population of the receiving country (1950-2000)

\begin{tabular}{lll}
\hline & Number (millions) & Share of total population (\%) \\
\hline Turkey & $?$ & $>10$ \\
West Germany (2000) & 5 & 8.1 \\
Japan & 6.25 & 7.6 \\
Portugal (1980) & 0.65 & 6.5 \\
Russia (2000) & 6 & 4.2 \\
Netherlands & 0.55 & 3.9 \\
France (1970) & 2 & 3.9 \\
United Kingdom (1970) & 2 & 3.6 \\
United States (2000) & 4.35 & 1.4 \\
Belgium (2000) & 0.125 & 1.2 \\
Italy (2000) & 0.55 & 0.9 \\
Spain (2000) & 0.18 & 0.4 \\
Total & 27.65 & \\
\hline
\end{tabular}

Source: U. Bosma, J. Lucassen and G. J. Oostindie (eds), Postcolonial migrants and identity politics: Europe, Russia, Japan and the United States in comparison, New York and Oxford: Berghahn, 2012, p. 5. 
based. The involvement of foreign powers such as the United States, Russia and France in the internal affairs of the countries within their military, economic and ideological orbit influenced the mental horizons of the local population and explains why not only those who worked for or directly depended on the foreign powers, but also others, were drawn to the centers of global power brokers. A considerable part of Latin American migration to the United States is explained by the political and economic activities of the 'informal' US empire. As such, these 'backward linkages' function quite similarly to the colonization and decolonization mechanisms.

5) Internal economic growth. Finally, we should mention the large-scale migrations attributable to spectacular economic growth within global macro-regions such as China and, to a lesser extent, South Africa. Although the globalizing effect of these migrations is less strong because the migrants largely remain within their cultural space, I have included these two cases of mass migration because they involve longdistance moves and are inextricably linked to the global economy, as well as being very similar to the two Asian systems distinguished in the first part of the period of 'thick globalization' (Map 2.4). These five factors have fundamentally changed the global migration systems since the 1950s, as can be seen in Map 2.5.

\section{Conclusion}

Combining the four indicators of globalization mentioned in the introduction (extensity, intensity, velocity and impact) with the CCMR model and applying it to the periodization used in this chapter produces the following result.

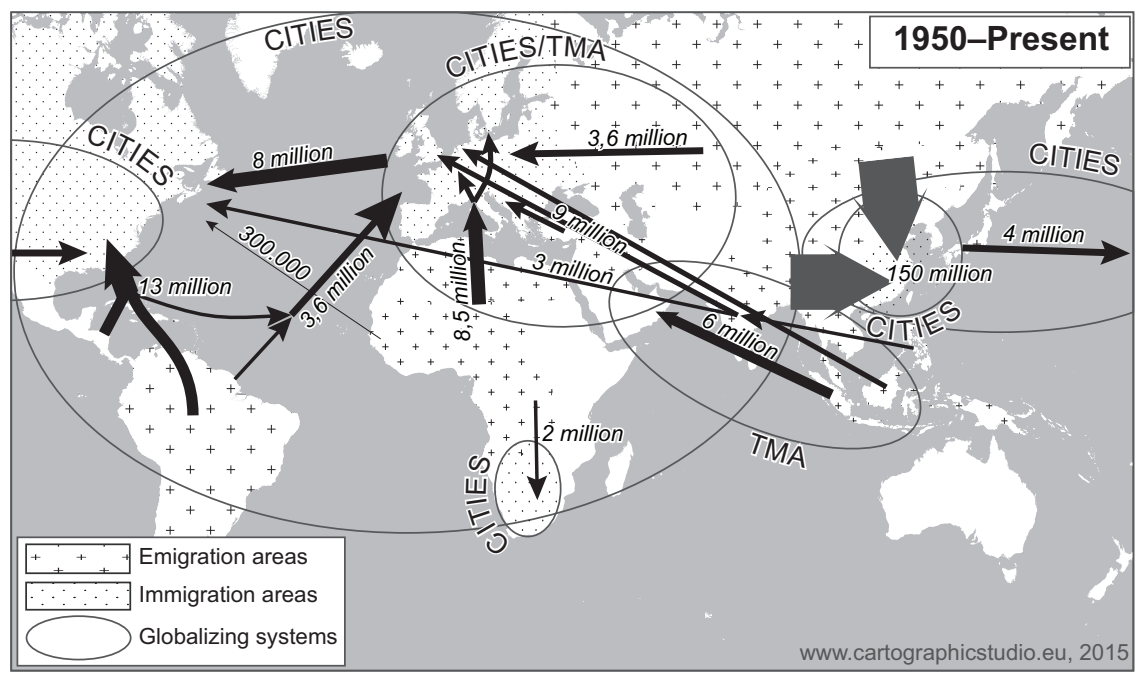

MAP 2.5 Five major globalizing systems of cross-cultural migrations (CCMs) since the 1950s. 
42 Leo Lucassen

TABLE 2.5 Relationship between key dimensions of globalization and cross-cultural migration in the second millennium

\begin{tabular}{|c|c|c|c|c|}
\hline & $\begin{array}{l}\text { Partial } \\
\text { globalization } \\
(1000-1492)\end{array}$ & $\begin{array}{l}\text { Thin } \\
\text { globalization } \\
(1492-1815)\end{array}$ & $\begin{array}{l}\text { Thick } \\
\text { globalization, } \\
\text { phase } 1 \\
(1815-1950)\end{array}$ & $\begin{array}{l}\text { Thick } \\
\text { globalization, } \\
\text { phase } 2 \\
\text { (1950- present) }\end{array}$ \\
\hline Extensity & + & ++ & $<$ & $<$ \\
\hline Intensity & + & + & ++ & $<$ \\
\hline Velocity & + & + & ++ & $<$ \\
\hline (Global cross-cultural) impact & + & + & ++ & $<$ \\
\hline Dominant CCM & TMA & $\begin{array}{l}\text { TMA/ } \\
\text { colonization }\end{array}$ & $\begin{array}{l}\text { To cities/ } \\
\text { TMA }\end{array}$ & To cities \\
\hline
\end{tabular}

Looking back at a millennium of migration movements between different parts of the world through the lens of the CCMR model, we see a clear shift from partial and thin to thick, and from segmented movements to movements encompassing human interactions. Moreover, this accelerating globalization is even more significant as the periods become shorter over time. This is not to say that present-day migration is free and universal. The human tragedies in the Mediterranean and on the southern border of the United States, as well as the massive flows of refugees in Africa and parts of Asia, remind us that we are still far removed from such an ideal world.

A second trend is in the type of cross-cultural migration. As the subsequent maps show, a clear change has taken place in those migrations characterized by TMA migrations (partly forced, as slaves); these have shifted, via colonization migrations (also partly forced, by indentured workers and slaves), to free migrations to cities around the world. In the last half-century, globalizing migrants have moved overwhelmingly to cities, with TMA being dominant only in the case of the Gulf states. As many indications suggest that cross-cultural contacts in cities are much more diverse, open and intensive than TMA (forced or otherwise) and Colonization migrations, we expect the impact of these migrations on the spread of ideas, practices and institutions to be much more pervasive than ever before.

This leaves us with the question of what the consequences of these globalizing migrations are. On the one hand, it could be assumed that cultural convergence will continue, due to the dominance of a limited number of cultural frames in terms of language (English and, to a lesser extent, Spanish), politics (Western democracy) and consumption patterns (standardized by multinationals). Yet, there still remain significant cultural differences between world regions. In China, Russia and other parts of the world it is not only the languages and political systems that diverge from those in the North Atlantic, but also the religions to them. Furthermore, many migrants do not enjoy the same rights as natives, including in the heartland of Anglo-Saxon globalization. Although this is most evident in the 
Middle East, there are also millions of illegal immigrants in the United States and Europe who are more or less excluded from open interactions. Lastly, in the past few decades the world has seen an opposite development of increasing nationalism, 'autochthony' and religious essentialism, ranging from anti-immigrant populism in Western Europe to Islamic State and Boko Haram in Africa and the Middle East, and state repression of minorities in India, China and Russia.

Nevertheless, there seems to be one domain in particular-the domain of production and consumption - in which globalization is very pervasive and to which the migrations shown on Map 2.5 are greatly contributing, alongside the globalization of capital. Although there are still vast differences in consumption patterns and tastes between and within continents, the level of uniformity has never been so high when it comes to the things we make, long for and buy. The extent to which this will also influence how we think and behave in the future remains to be seen.

\section{Notes}

1 I would like to thank Irial Glynn, Leslie Moch, Jan Lucassen and the editors for their comments on an earlier version.

2 P. Manning, Migration in world history, 2nd edn, Abingdon; New York: Routledge, 2013.

3 J. Lucassen and L. Lucassen (eds), Globalising migration history. The Eurasian experience (16th21st centuries), Leiden; Boston, MA: Brill, 2014.

4 Inspired by P. Manning, Migration in world history, New York; London: Routledge, 2005.

5 So far the only global overviews are: D. Hoerder, Cultures in contact. World migrations in the second millennium, Durham, NC; London: Duke University Press, 2002; Manning, Migration in world history, 2013; J. Lucassen, L. Lucassen and P. Manning (eds) Migration history in world history. Multidisciplinary approaches, Leiden; Boston, MA: Brill, 2010.

6 K. Pomeranz, The great divergence: China, Europe, and the making of the modern world economy, Princeton, NJ: Princeton University Press, 2010; N. Breyfogle, A. Schrader and W. Sunderland (eds), Peopling the Russian periphery: borderland colonization in Eurasian history, London; New York: Routledge, 2007; R. Kasaba, A moveable empire. Ottoman nomads, migrants E refugees. Seattle, WA; London: The University of Washington Press, 2009; S. E. Ramírez, Kings, kinsmen and others: the theory and practice of Andean allegiances , in U. Bosma, G. Kessler and L. Lucassen (eds), Migration and membership regimes in global and historical perspective, Leiden: Brill, 2013, pp. 221-38.

$7 \mathrm{~J}$. Burbank and F. Cooper, Empires in world history. Power and the politics of difference, Princeton, NJ; Oxford: Princeton University Press, 2010.

8 M. Tymowski, Early imperial formations in Africa and the segmentation of power, in P. F. Bang and C. A. Bayly (eds), Tributary empires in global history, Basingstoke: Palgrave Macmillan, 2011, pp.108-19.

9 W. Hawthorne, From Africa to Brazil: Culture, identity, and an Atlantic slave trade, 1600-1830, Cambridge: Cambridge University Press, 2010; M. Jasanoff, 'Revolutionary exiles: the American loyalist and French émigré diasporas', in D. Armitage and S. Subrahmanyam (eds), The age of revolutions in global context, c. 1760-1840, New York: Palgrave Macmillan, 2010, pp. 37-58. More general: Hoerder, Cultures in contact, 2002

10 D. Armitage and S. Subrahmanyam (eds) The age of revolutions in global context, $c$. 1760-1840, New York: Palgrave Macmillan, 2010.

11 L. Lucassen and W. Willems (eds), Living in the city. Urban institutions in the Low Countries, 1200-2010. New York; London: Routledge, 2012; U. Bosma, G. Kessler and L. Lucassen (eds), Migration and membership regimes in global and historical perspective, Leiden; Boston, MA: Brill, 2013. 


\section{Leo Lucassen}

12 D. C. North, J. J. Wallis et al., Violence and social orders. A conceptual framework for interpreting recorded human history, Cambridge: Cambridge University Press, 2009.

13 G. Kessler and J. Lucassen, Labour relations, efficiency and the great divergence. Comparing pre-industrial brick-making across Eurasia, 1500-2000, in M. Prak and J. L. van Zanden (eds), Technology and human capital formation in East and West, Leiden; Boston, MA: Brill, 2013, pp. 259-322.

14 W. Nugent, Crossings: the great transatlantic migrations, 1870-1914, Bloomington, IN: Indiana University Press, 1992.

15 Kasaba, A moveable empire, 2009.

16 L. Lucassen and A. X. Smit, 'The repugnant other: soldiers, missionaries and aid workers as organizational migrants', The Journal of World History (forthcoming 2015).

17 D. Nicolle, Armies of the Ottoman Empire 1775-1820, Oxford; New York: Osprey, 1998.

18 U. Bosma, Sailing through Suez from the south: the emergence of an Indies-Dutch migration circuit, 1815-1940, International Migration Review, 41(2), 2007, 511-36; U. Bosma, 'European colonial soldiers in the nineteenth century: their role in white global migration and patterns of colonial settlement', The Journal of Global History, 4(2), 2009, 317-36; J. Osterhammel, The transformation of the world: a global history of the nineteenth century, Princeton, NJ: Princeton University Press, 2014, p. 887; L. H. Siegelbaum and L. P. Moch, Broad is my native land: repertoires and regimes of migration in Russia's twentieth century, Ithaca, NY; London: Cornell University Press, 2014.

19 Manning, Migration in world history, 2013, p. 94. As early as 1400, pilgrims from these regions followed the Qur'an's call to travel to Mecca. I. Back, 'From West Africa to Mecca and Jerusalem: the Tijāniyya on the Hajj routes', The Journal of Middle East and Africa, 6(1), 2015, 1-15.

20 T. Asbridge, The first crusade: a new history, Oxford: Oxford University Press, 2004, p. 89.

21 For more details, see: Lucassen and Lucassen, Globalising migration histor $\gamma, 2014$.

22 K. H. O'Rourke and J. G. Williamson, Globalization and history. The evolution of a nineteenth-century Atlantic economy, Cambridge, MA: MIT Press, 2000; K. H. O'Rourke and J. G. Williamson, 'When did globalization begin?', European Review of Economic History, 6(1), 2002, 23-50. And the response by D. O. Flynn and A. Giráldez, 'Path dependence, time lags and the birth of globalisation: a critique of O'Rourke and Williamson', European Review of Economic History, 8(1), 2004, 81-108.

23 P. Jackson, 'Turkish slaves on Islam's Indian frontier', in I. Chatterjee and R. M. Eaton (eds), Slavery and South Asian history, Bloomington, IN: Indiana University Press, 2006, p. 70 .

24 J. Fynn-Paul, 'Empire, monotheism and slavery in the greater Mediterranean region from antiquity to the early modern era', Past and Present, 205(1), 2009, 3-40; E. R. Toledano, Slavery and abolition in the Ottoman Middle East, Seattle, WA: University of Washington Press, 1998; C. V. Findley, The Turks in world history, Oxford: Oxford University Press, 2005, p. 67-8.

25 T. Allsen, 'The rise of the Mongolian Empire and Mongolian rule in North China', in D. Twitchett and H. Franke (eds), The Cambridge history of China, Cambridge: Cambridge University Press, 1994, pp. 321-413.

26 M. H. Fisher, Migration: a world history, Oxford: Oxford University Press, 2014, p. 42.

27 T. Barfield, The perilous frontier: nomadic empires and China, 221 BC to AD 1757. Oxford: Basil Blackwell, 1989.

28 Fisher, Migration: a world history, p. 42. T. Allsen, Commodity and exchange in the Mongol Empire. A cultural history of Islamic textiles, Cambridge: Cambridge University Press, 1997, pp. 99-101.

29 N. Levtzion, The Western Maghrib and Sudan , in R. Oliver (ed.), The Cambridge history of Africa, Cambridge: Cambridge University Press, 1997, pp. 331-6.

30 Levtzion, The Western Maghrib and Sudan , p. 348; C. El Hamel, Black Morocco: a history of slavery, race, and Islam, Cambridge: Cambridge University Press, 2013, pp. 212-28. 
31 R. A. Austen, 'The Trans-Saharan slave trade: a tentative census', in H. A. Gemery and J. S. Hagendorn (eds), The uncommon market: essays in the economic history of the Atlantic slave trade, Boston, MA: Boston University African Studies Centre, 1979, p. 66; P. Curtin, Cross-cultural trade in world history, Cambridge: Cambridge University Press, 1984, p. 21; J. D. Fage, A history of Africa, London: Routledge, 2002; A. Stanziani, Sailors, slaves, and immigrants. Bondage in the Indian Ocean world, 1750-1914, New York: Palgrave, 2014, Chapter 4.

32 J. D. Richards, The Vikings: a very short introduction, Oxford: Oxford University Press, 2006.

33 My estimate, based on J. Phillips, The Crusades 1095-1204, London; New York: Routledge, 2014, pp. 19, 24, 51 and 53. See also T. F. Madden, The concise history of the Crusades, Lanham, MD: Rowman and Littlefield, 2014, pp. 9-15.

34 Phillips, The Crusades 1095-1204, 2014, p. 19.

35 Austen, 'The Trans-Saharan slave trade', 1979, p. 66; R. A. Austen, Trans-Saharan Africa in World History, Oxford: Oxford University Press, 2010, p. 32.

36 R. Pankhurst, An introduction to the economic history of Ethiopia from early times to 1800, London: Lalibela House, 1961, p. 374; R. W. Beachey, The slave trade of Eastern Africa, New York: Barnes and Noble, 1976, p. 4; H. Basu, Slave, soldier, trader, faqir. Fragments of African histories in Western India (Gujarat), in S. de Silva Jayasuriya and R. Pankhurst (eds), The African Diaspora in the Indian Ocean, Trenton, NJ: African World Press, 2003, pp. 226-8; M. A. Klein, 'Slavery: Mediterranean, Red Sea, Indian Ocean', in K. Shillington (ed.), Encyclopedia of African history, New York: Routledge, 2004.

37 J. Hooper and D. Eltis, 'The Indian Ocean in Transatlantic Slavery', Slavery and Abolition, 34(3), 2013, 353-75.

38 N. Sánchez-Albornoz, 'The first transatlantic transfer: Spanish migration to the New World, 1493-1810', in N. Canny (ed.), Europeans on the move. Studies on European migration, 1500-1800, Oxford: Clarendon Press, 1994, p. 30.

39 D. Galenson, White servitude in colonial America. An economic analysis, Cambridge: Cambridge University Press, 1981; J. Wareing, Emigrants to America. Indentured servants recruited in London 1718-1733, Baltimore, MD: Genealogic Publishing, 1985; S. V. Salinger, 'To serve well and faithfully'. Labor and indentured servants in Pennsylvania, 1682-1800, Cambridge: Cambridge University Press, 1987.

40 P. Clark, 'Introduction', in P. Clark (ed.), The Oxford handbook of cities in world history, Oxford: Oxford University Press, 2013, p. 12.

41 P. Manning and S. Nickleach, African population, 1650-1950: the eras of enslavement and colonial rule, Pittsburgh, PA: Center for World History, 2014, p. 87.

42 Manning and Nickleach, African population, 2014, p. 167, Table 12.1

43 A. W. Crosby, Germs, seeds and animals. Studies in ecological history, New York: M. E. Sharpe, 1994, pp. 21-5.

44 S. Bono, Schiavi musulmani nell'Italia moderna. Galeotti, vu' cumpra', domestici, Napoli: Edizioni Scientifiche Italiane, 1999; J. Lucassen and L. Lucassen, 'The mobility transition in Europe revisited, 1500-1900: sources and methods', IISH Research Papers, Amsterdam: International Institute of Social History, 2010, p. 17.

45 W. Clarence-Smith, Islam and the abolition of slavery, London: Hurst, 2006.

46 Nicolle, Armies of the Ottoman Turks 1300-1744, Oxford: Osprey Publishing, 1983. D. Nicolle, Armies of the Ottoman Empire, 1998.

47 Kasaba, A moveable empire, 2009.

48 K. N. Chaudhuri, Asia before Europe: economy and civilisation of the Indian Ocean from the rise of Islam to 1750, Cambridge: Cambridge University Press, 1990; P. Beaujard, The Indian Ocean in Eurasian and African world systems before the sixteenth century, Journal of World History, 16 4), 2005, 411-65; M. P. M. Vink, 'Indian Ocean studies and the "new thalassology", Journal of Global History, 2(1), 2007, 41-62; E. Ho, The graves of Tarim: genealogy and mobility across the Indian Ocean, Berkeley, CA: University of California Press, 2006. 


\section{Leo Lucassen}

49 J. Lucassen, 'The Netherlands, the Dutch, and long-distance migration in the late sixteenth to early nineteenth centuries', in N. Canny (ed.), Europeans on the move. Studies on European migration, 1500-1800, Oxford: Clarendon Press, 1994, pp. 153-91.

50 J. Bruijn and F. Gaastra, Ships, sailors and spices, Amsterdam: NEHA, p. 183

51 L. Brockey, Journey to the East: the Jesuit mission to China, 1675-1724, Cambridge, MA: Harvard University Press, 2007.

52 B. J. ter Haar, Het hemels mandaat. De geschiedenis van het Chinese keizerrijk, Amsterdam: Amsterdam University Press, 2009, pp. 346-8.

53 D. S. Fitzgerald and D. Cook-Martín, Culling the masses: the democratic origins of racist immigration policy in the Americas, Cambridge, MA: Harvard University Press, 2014, p. 270; A. McKeown, Chinese migrant networks and cultural change. Peru, Chicago, Hawaii, 1900-1936, Chicago, IL; London: Chicago University Press, 2001.

54 D. Audy, Les zouaves de Québec au XXe siècle, Quebec: Presses de l'Université Laval, 2003.

55 Bosma, 'European colonial soldiers in the nineteenth century', 2009, pp. 317-36.

56 M. Höhn and M. Klimke, A breath of freedom: the civil rights struggle, African American GIs, and Germany, New York: Palgrave Macmillan, 2010.

57 G. Weeks, 'Immigration', in A. McPherson (ed.), Encyclopedia of US military interventions in Latin America, Santa Barbara: ABC-Clio, 2013, pp. 307-9.

58 Lucassen and Smit, 'The repugnant other', 2015.

59 Siegelbaum and Moch, Broad is my native land, 2014, pp. 164-6.

$60 \mathrm{~J}$. F. Hollifield, Immigrants, markets, and states: the political economy of postwar Europe, Cambridge MA: Harvard University Press, 1992; L. Lucassen, The immigrant threat: the integration of old and new migrants in Western Europe since 1850, Urbana; Chicago, IL: The University of Illinois Press, 2005; L. Lucassen and J. Lucassen, 'The strange death of Dutch tolerance: the timing and nature of the pessimist turn in the Dutch migration debate', The Journal of Modern History, 87(1), 2015, 72-101.

61 C. Joppke, Selecting by origin. Ethnic migration in the liberal state, Cambridge, MA: Harvard University Press, 2005; U. Bosma, J. Lucassen and G. J. Oostindie, 'Introduction. Postcolonial migrations and identity politics: towards a comparative perspective', in U. Bosma, J. Lucassen and G. J. Oostindie (eds), Postcolonial migrants and identity politics: Europe, Russia, Japan and the United States in comparison, New York; Oxford: Berghahn, 2012, pp. 1-22.

62 L. Douw, C. Huang and D. Ip (eds), Rethinking Chinese transnational enterprises: cultural affinity and business strategies, Richmond, Surrey: Curzon Press, 2001 